\title{
Catalyst property effects on product distribution during the hydrodeoxygenation of lignin pyrolysis vapors over $\mathrm{MoO}_{3} / \mathrm{Y}-\mathrm{Al}_{2} \mathrm{O}_{3}$
}

Alireza Saraeian ${ }^{a, b}$, Sadie J. Burkhowc, Dapeng Jingd, Emily A. Smithc, Brent H. Shanks*a,b

a Department of Chemical and Biological Engineering, lowa State University, Ames, IA 50011, United States

${ }^{b}$ Research Center for Biorenewable Chemicals (CBiRC), Ames, IA 50011, USA

c The Ames Laboratory, U.S. Department of Energy, and Department of Chemistry, lowa State University, Ames, IA 50011, United States

d Materials Analysis and Research Laboratory, lowa State University, Ames, IA 50011, United States

*: E-mail: bshanks@iastate.edu; Fax: 01515294 2689; Tel: 015152941895

The supporting information includes a detailed experimental section and:

- $\quad$ Figure S1. Effect of catalyst-to-lignin ratio on products from HDO of lignin pyrolysis vapors

- Figure S2. Various transition metal oxides for HDO of lignin pyrolysis vapors

- Figure S3. $\mathrm{N}_{2}$-adsorption/desorption isotherms of the catalysts samples

- $\quad$ Figure S4. Pore size distribution of catalyst samples

- $\quad$ Figure S5. DRITFS of pyridinated samples evacuated at 423-623 K

- $\quad$ Figure S6. XRD patterns of the catalyst samples

- $\quad$ Figure S7. XPS spectra of the catalyst samples

- $\quad$ Figure S8. Optical images of the catalyst samples (Raman)

- $\quad$ Figure S9. Coke combustion of used catalysts HDO of various feedstocks

- $\quad$ Figure S10. Coke combustion of used catalysts after HDO of DPL

- Table S1. List of compounds used for GC calibration

- Table S2. Raman peak assignments of $\mathrm{MoO}_{3}$

- Table S3. Carbon yield of products from the HDO of anisole

- Table S4. Carbon yield of products from the HDO of 4-propylphenol

- Table S5. Carbon yield of products from the HDO of 2-butanone

- $\quad$ Table S6. Carbon yield of products from the HDO of DPL pyrolysis vapors 


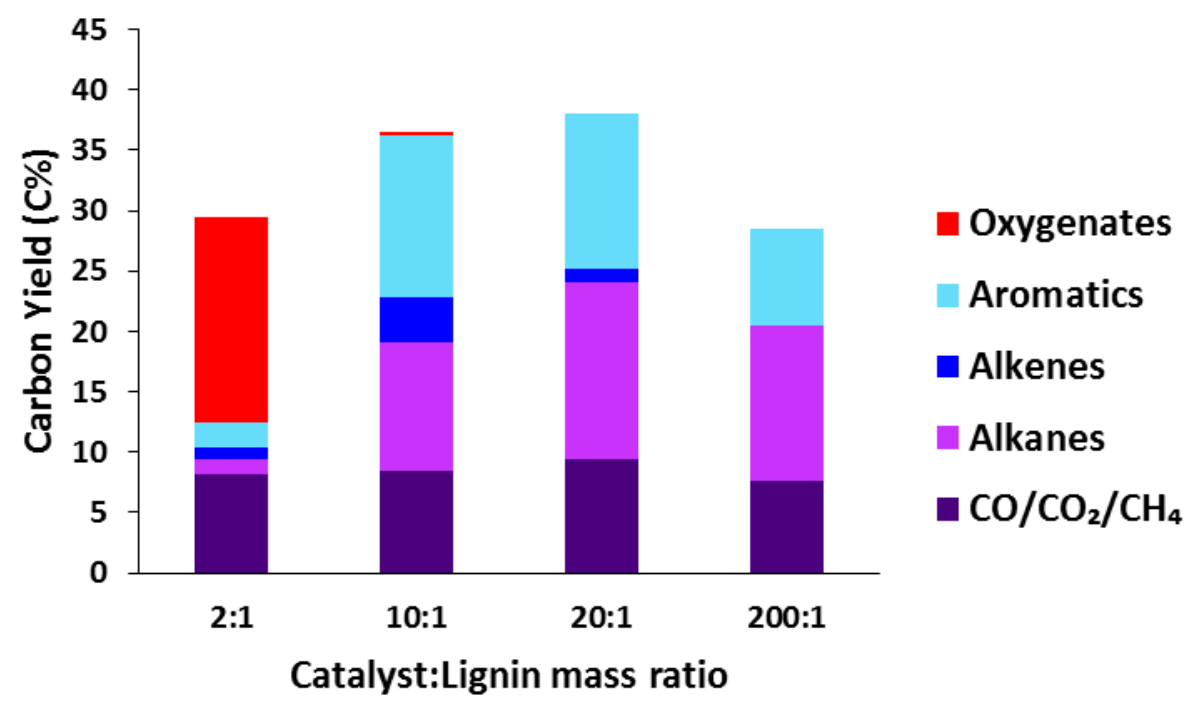

Figure S1. Products from HDO of Organosolv cornstover lignin pyrolysis vapors using different loadings of $\mathrm{MoO}_{3}$ (Conditions: $\mathrm{T}_{\mathrm{py}}=773 \mathrm{~K} ; \mathrm{T}_{\mathrm{HDO}}=673 \mathrm{~K}, 120 \mathrm{ml} \mathrm{min}^{-1} \mathrm{H}_{2}$ at $\sim 1.7 \mathrm{bar}, 0.3 \mathrm{mg}$ lignin)

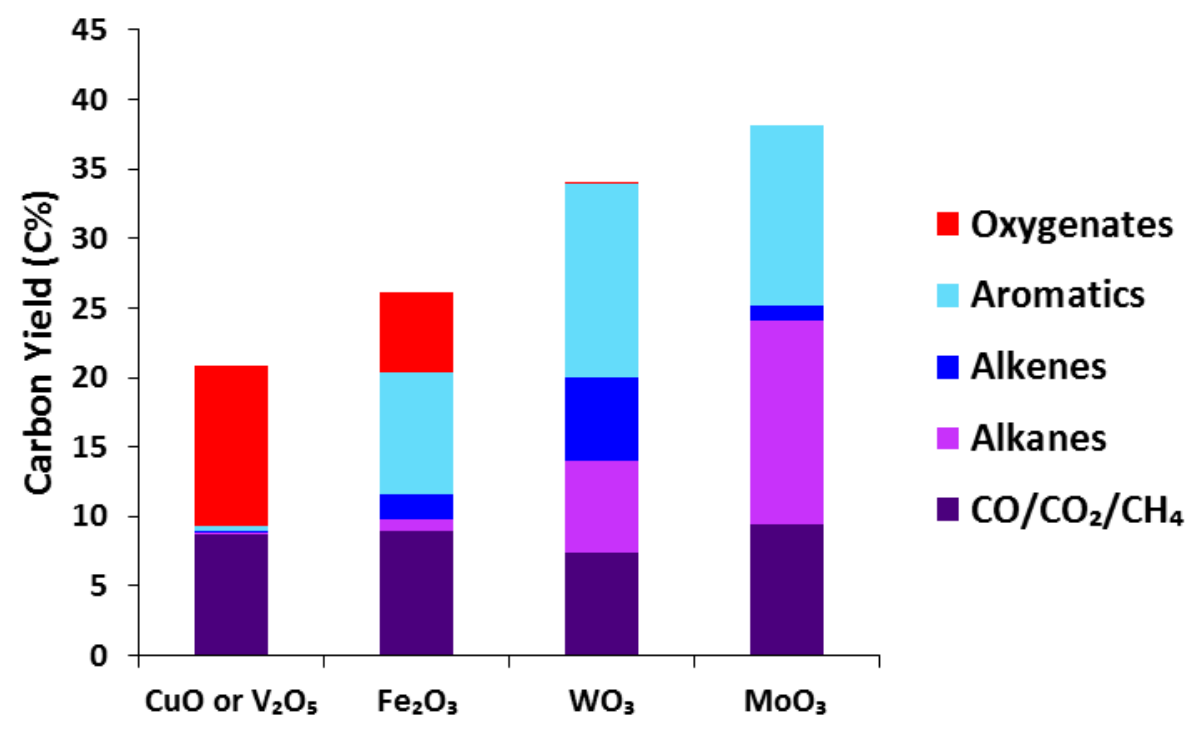

Figure S2. Products from HDO of Organosolv cornstover lignin pyrolysis vapors over some transition metal oxides (Conditions: $\mathrm{T}_{\mathrm{py}}=773 \mathrm{~K} ; \mathrm{T}_{\mathrm{HDO}}=673 \mathrm{~K}, 120 \mathrm{ml} \mathrm{min} \mathrm{m}^{-1} \mathrm{H}_{2}$ at $\sim 1.7 \mathrm{bar}, \sim 0.3 \mathrm{mg}$ lignin, catalyst:lignin mass ratio=20) 


\section{Experimental}

\subsection{Materials and catalyst synthesis}

The model compounds anisole (99\%, Acros Organics), 4-propylphenol (>99\%, TCI), and 2-butanone (99.8\%, Fisher) were used without further purification. Calibration compounds were purchased from various sources and used without any purification (Table S1). DuPont lignin (DPL) extracted from corn stover using a proprietary mild ammonia-based extraction method was obtained from DuPont Company and used with no further treatment. Ultra-high purity hydrogen, helium, and argon, and ultra-zero air gas cylinders were purchased from Airgas and used for these experiments.

Catalyst synthesis was done using a conventional wet impregnation method. For each sample, a specific amount of ammonium molybdate tetrahydrate (99.98\% trace metal basis, Sigma-Aldrich) was dissolved in $20 \mathrm{ml}$ of nanopure water. This solution was then added to a beaker containing $5 \mathrm{~g}$ of $\mathrm{\gamma}-\mathrm{Al}_{2} \mathrm{O}_{3}\left(1 / 16^{\prime \prime}\right.$ pellets, Strem Chemicals) and stirred overnight. The impregnated $y-\mathrm{Al}_{2} \mathrm{O}_{3}$ was dried at $383 \mathrm{~K}$ for $12 \mathrm{~h}$ in an oven and calcined at $773 \mathrm{~K}$ for $4 \mathrm{~h}$ with a temperature ramp of $10 \mathrm{~K} / \mathrm{min}$ in a muffle furnace under static air. The samples were denoted $x M o A l$, where $x$ represents the $w t \% \mathrm{MoO}_{3}$ content of the catalyst based on Mo. For example, $11 \mathrm{MoAl}$ is the catalyst with $\sim 11 \mathrm{wt} \% \mathrm{MoO}_{3}$ equivalent supported on $\mathrm{\gamma}-\mathrm{Al}_{2} \mathrm{O}_{3}$. Bare $\mathrm{\gamma}$ $\mathrm{Al}_{2} \mathrm{O}_{3}$ support and bulk molybdenum (VI) oxide $\left(\mathrm{MoO}_{3}, \geq 99.5 \%\right.$, Sigma-Aldrich) underwent a similar thermal treatment before use. All catalysts were crushed and sieved to a mesh size of 140-400 (38-106 $\mu \mathrm{m})$ and kept in a desiccator before reactions.

Table S1. List of compounds used for FID and TCD calibration*

\begin{tabular}{|c|c|c|c|c|}
\hline & Compound & & Category & Detector \\
\hline $5 \% \mathrm{CO}$ & $5 \% \mathrm{CO}_{2}$ & 2\% Methane & $\begin{array}{c}\mathrm{CO} \\
\mathrm{CO}_{2} \\
\text { Methane }\end{array}$ & TCD \\
\hline $\begin{array}{l}2 \% \text { Ethane } \\
2 \% \text { Propane }\end{array}$ & $\begin{array}{l}1 \% \text { iso-Butane } \\
2 \% \text { n-Butane }\end{array}$ & $2 \%$ n-Pentane & Alkanes & TCD \\
\hline $\begin{array}{l}2 \% \text { Ethylene } \\
2 \% \text { Propylene }\end{array}$ & $\begin{array}{c}\text { 4\% 1-Butene } \\
2 \% \text { cis-2-Butene }\end{array}$ & $\begin{array}{c}\text { 1\% trans-2-Butene } \\
1 \% 1 \text {-Pentene }\end{array}$ & Alkenes & TCD \\
\hline n-Hexane & Cyclohexane & Methylcyclohexane & Alkanes & TCD/FID \\
\hline $\begin{array}{l}\text { 1-Hexene } \\
\text { Cyclohexene }\end{array}$ & $\begin{array}{l}\text { 2-Methyl-1-pentene } \\
\text { 1-Octene }\end{array}$ & $\begin{array}{c}\text { 1-Methylcyclopentene } \\
\text { 1,7-Octadiene }\end{array}$ & Alkenes & TCD/FID \\
\hline $\begin{array}{l}\text { Benzene } \\
\text { Toluene } \\
\text { Ethylbenzene } \\
\text { o-Xylene }\end{array}$ & $\begin{array}{c}\text { m-Xylene } \\
\text { p-Xylene } \\
\text { Mesitylene }\end{array}$ & $\begin{array}{c}\text { n-Propylbenzene } \\
\text { 1,4-Diethylbenzene } \\
\text { Pentamethylbenzene }\end{array}$ & MAR & FID \\
\hline $\begin{array}{c}\text { Naphthalene } \\
\text { 1-Methylnaphthalene }\end{array}$ & Indane & Indene & DAR & FID \\
\hline Fluorene & Anthracene & & PAH & FID \\
\hline
\end{tabular}




\begin{tabular}{|c|c|c|c|c|}
\hline $\begin{array}{c}\text { Acetic acid } \\
\text { Propionic acid } \\
\text { Methanol } \\
\text { Acetone } \\
\text { Propanal } \\
\text { Hydroxyacetone } \\
\text { Furan } \\
\text { 2-Methylfuran }\end{array}$ & $\begin{array}{c}\text { 2,5-Dimethylfuran } \\
\text { Furfural } \\
\text { Furfuryl alcohol } \\
\text { 5-Hydroxymethylfurfural } \\
\text { 2-Butanone } \\
\text { 2-Hexanone } \\
\text { Cyclopentanone } \\
\text { 2-Octanone }\end{array}$ & $\begin{array}{l}\text { 2-Cyclopenten-1-one } \\
\text { 2,3-Butanedione } \\
\text { gamma-Valerolactone } \\
\text { Methyl formate } \\
\text { Methyl pyruvate } \\
\text { Methyl lactate } \\
\text { Levoglucosan }\end{array}$ & $\begin{array}{c}\text { Non- } \\
\text { phenolics }\end{array}$ & FID \\
\hline $\begin{array}{c}\text { Phenol } \\
\text { o-Cresol } \\
\text { m-Cresol } \\
\text { p-Cresol } \\
\text { 4-Ethylphenol } \\
\text { 4-Propylphenol } \\
\text { 2,5-Dimethylphenol } \\
\text { Catechol } \\
\text { 4-Vinylphenol } \\
\text { 2-Allylphenol } \\
\text { 2-secbutylphenol } \\
\text { Vanillin } \\
\text { Eugenol }\end{array}$ & $\begin{array}{c}\text { Anisole } \\
\text { 4-Methylanisole } \\
\text { 4-Ethylanisole } \\
\text { 3,4-Dimethoxytoluene } \\
\text { 1,2,4-Trimethoxybenzene } \\
\text { Guaiacol } \\
\text { Creosol } \\
\text { 4-Ethylguaiacol } \\
\text { 4-Vinylguaiacol } \\
\text { 4-Propylguaiacol } \\
\text { Isoeugenol (cis/trans) } \\
\text { 2,3-Dihydrobenzofuran } \\
\text { Butylated Hydroxytoluene }\end{array}$ & $\begin{array}{c}\text { Syringol } \\
\text { 4-Allylsyringol } \\
\text { Syringaldehyde } \\
\text { Acetosyringone } \\
\text { Acetophenone } \\
\text { 3',5'-Dimethoxyacetophenone } \\
\text { 4'-Hydroxy-3'- } \\
\text { methoxyacetophenone } \\
\text { Benzaldehyde } \\
\text { 4-Propylbenzaldehyde } \\
\text { 4-Hydroxybenzaldehyde } \\
\text { 2-Methoxybenzaldehyde } \\
\text { 2,6-Dimethoxybenzaldehyde }\end{array}$ & Phenolics & FID \\
\hline $\begin{array}{c}\text { Pyrrole } \\
\text { 2,5-Dimethylpyrrole }\end{array}$ & Caprolactam & N-hydroxy succinimide & $\begin{array}{c}\text { Nitrogen } \\
\text { compounds }\end{array}$ & FID \\
\hline
\end{tabular}

\subsection{Catalyst Characterization}

$\mathrm{MoO}_{3}$ loadings were determined by an inductively coupled plasma-optical emission spectrometer (ICP-EOS) - PerkinElmer Optima 8000 (Shelton, CT) equipped with WinLab 32 software. Mo was monitored using the detector at $202.031 \mathrm{~nm}$. Catalyst samples and a fresh mixture of $\mathrm{HNO}_{3}$ (Fisher) and $\mathrm{HCl}$ (Fisher) with a volume ratio of 1 to 4 (known as aqua regia) were loaded in clean crucibles and kept overnight to ensure dissolution. The samples were then diluted 10 -fold in volumetric flasks using nanopure water and prepared for analysis. Calibration solutions were also diluted using $10 \%$ aqua regia to a range of 1-25 ppm from a stock solution containing 50 ppm Mo (Inorganic Ventures).

$\mathrm{N}_{2}$-physisorption experiments were performed using a Micromeritics ASAP 2020 instrument at $77 \mathrm{~K}$ to determine three properties: specific surface area of the samples using the Brunauer-Emmett-Teller (BET) method, total pore volume using the single point adsorption method at a relative pressure of 0.99 , and pore size distribution from the desorption branch of the Barrett-Joyner-Halenda (BJH) method. Before the analysis, samples ( $0.1 \mathrm{~g}$ ) were degassed at $373 \mathrm{~K}$ for $1 \mathrm{~h}$ under $10 \mu \mathrm{m} \mathrm{Hg}$ vacuum. In the case of $\mathrm{MoO}_{3}$, $\mathrm{N}_{2}$ physisorption was measured for both fresh and reduced samples. Approximately $0.2 \mathrm{~g}$ of $\mathrm{MoO}_{3}$ was reduced for $1 \mathrm{~h}$ at $673 \mathrm{~K}(25 \mathrm{~K} / \mathrm{min})$ in a tube furnace under $200 \mathrm{ml} \mathrm{min}^{-1} \mathrm{of}_{2}$. After reduction, the sample 
was cooled to $295 \mathrm{~K}$ and passivated using $2 \%$ air (balance $\mathrm{N}_{2}$ ) for $2 \mathrm{~h}$. About $0.1 \mathrm{~g}$ of this sample was immediately loaded into a quartz bulb for $\mathrm{N}_{2}$ physisorption after removal from the tube furnace.

Ammonia temperature-programmed desorption ( $\mathrm{NH}_{3}$-TPD) tests were performed using a Micromeritics AutoChem II 2920 equipped with a thermal conductivity detector (TCD). Approximately $0.1 \mathrm{~g}$ of each catalyst sample was loaded in a U-shaped quartz tube. The temperature was increased to $673 \mathrm{~K}$ at a rate of $20 \mathrm{~K} / \mathrm{min}$ and held for $60 \mathrm{~min}$ under $100 \mathrm{ml} \mathrm{min}^{-1}$ of $\mathrm{H}_{2}$ to reduce the catalyst in-situ. The sample was then cooled to $373 \mathrm{~K}$, and the flow switched to $20 \mathrm{ml} \mathrm{min}^{-1} \mathrm{He}$ before exposing it to $20 \mathrm{ml} \mathrm{min}^{-1}$ of a gas stream containing $10 \% \mathrm{NH}_{3}$ (balance He) for $1 \mathrm{~h}$. Next, the gas flow was switched to $20 \mathrm{ml} \mathrm{min} \mathrm{m}^{-1} \mathrm{He}$ to completely purge excess ammonia out of the system, manifested as no change in the TCD signal. The sample temperature was then ramped from $373 \mathrm{~K}$ to $923 \mathrm{~K}$ at a rate of $10 \mathrm{~K} / \mathrm{min}$ and ammonia desorbed from the catalyst sample was measured using the TCD. The temperature was monitored and controlled using a K-type thermocouple in direct contact with the sample.

Diffuse reflectance Fourier transform infrared spectroscopy (DRIFTS) was done using a Tensor 27 (Bruker) with Ma IR source, $\mathrm{KBr}$ beamsplitter, and DLaTGS detector equipped with a Praying Mantis ${ }^{\mathrm{TM}}$ diffuse reflectance cell and high temperature reaction chamber (Harrick Scientific) with $\mathrm{CaF}_{2}$ windows. The FTIR instrument was operated at a $2.2 \mathrm{KHz}$ scan speed and resolution of $4 \mathrm{~cm}^{-1}$, collecting 50 scans per spectrum. The sample cup was loaded with the catalyst, lightly pressed into a pellet. The sample (previously held in a desiccator) was heated to $423 \mathrm{~K}$ under flowing Ar for $30 \mathrm{~min}$ to remove any adsorbed water. Temperature was controlled using an EZ-Zone ${ }^{\circledR}$ PID controller (Watlow) and a K-type thermocouple located just underneath the sample cup. The sample was reduced under flowing $\mathrm{H}_{2}(60 \mathrm{~mL}$ $\mathrm{min}^{-1}$ ) at $673 \mathrm{~K}$ for $1 \mathrm{~h}$ inside the reaction chamber to avoid any contact with air before analysis. After cooling the sample to $423 \mathrm{~K}$ and switching Ar flow, a background spectrum was collected. Pyridine (99.8\%, Fisher) was fed into the chamber using a bubbler and flow of $\operatorname{Ar}\left(60 \mathrm{mLmin}^{-1}\right)$ passing through PTFE tubing. Each sample was exposed to the pyridine-rich flow for $15 \mathrm{~min}$ at $423 \mathrm{~K}$ to ensure that enough pyridine was available to saturate the acid sites. The sample was then degassed under flowing $\operatorname{Ar}$ for $1 \mathrm{~h}$ at that temperature to desorb any phisysorbed or weakly chemisorbed pyridine from the surface. The FTIR spectra were collected at 423,523 , and $623 \mathrm{~K}$ to gain insights into the relative strength of Lewis and Brønsted acid sites. The results of FTIR tests were analyzed using OPUS 6.5 software.

Powder X-ray Diffraction (XRD) measurements were done using a Siemens D500 diffractometer with a Cu tube operated at $45 \mathrm{kV}$ and $30 \mathrm{~mA}$ and a carbon diffracted beam monochromator. Approximately $250 \mathrm{mg}$ 
of each sample was mounted in a $20 \mathrm{~mm}$ stainless steel holder, and data were collected between $2 \theta$ values of $20-70^{\circ}$. The diffraction patterns were normalized to maximum peak intensity for each catalyst.

The X-ray photoelectron spectroscopy (XPS) measurements were performed using a Kratos Amicus/ESCA 3400 instrument. The sample was irradiated with $240 \mathrm{~W}$ unmonochromated $\mathrm{Mg} K \alpha \mathrm{x}$-rays, and photoelectrons emitted at $0^{\circ}$ from the surface normal were energy analyzed using a DuPont type analyzer. The pass energy was set at $150 \mathrm{eV}$, and either a Shirley or linear baseline were removed from all reported spectra. CasaXPS was used to process raw data files.

Hydrogen temperature-programmed reduction $\left(\mathrm{H}_{2}-\mathrm{TPR}\right)$ was conducted using the same AutoChem II 2920 connected to a MicroStar mass spectrometer (MS). Samples were loaded into U-shaped quartz tubes and dried at $393 \mathrm{~K}$ for $1 \mathrm{~h}$ under $25 \mathrm{ml} \mathrm{min}-1$ Ar. The temperature was then lowered to $323 \mathrm{~K}$ before the gas stream was changed to a mixture of $\mathrm{H}_{2}\left(1 \mathrm{ml} \mathrm{min}^{-1}\right), \operatorname{Ar}\left(9 \mathrm{ml} \mathrm{min} \mathrm{m}^{-1}\right)$, and $\mathrm{He}\left(40 \mathrm{ml} \mathrm{min}^{-1}\right)$. The sample temperature was then increased to $973 \mathrm{~K}$ at a rate of $5 \mathrm{~K} / \mathrm{min}$, and $\mathrm{H}_{2}, \mathrm{H}_{2} \mathrm{O}$, and $\mathrm{Ar}$ were monitored using the signals at $m / z=2,18$, and 40 , respectively. To keep the $\mathrm{H}_{2} / \mathrm{MoO}_{3}$ ratio the same, $\sim 20 \mathrm{mg}$ equivalent of $\mathrm{MoO}_{3}$ was used for supported and bulk catalysts, and the consumption of $\mathrm{H}_{2}$ (normalized by $\mathrm{Ar}$ as an internal standard) as a function of sample temperature was reported.

An XploRA Plus Raman confocal upright microscope (HORIBA Scientific, Edison, New Jersey) with a Synapse EMCCD camera was used to collect all Raman data. A 532-nm solid state diode laser with an irradiance of $14,000 \mathrm{~W} / \mathrm{cm}^{2}$ was used for all materials. The optical images and Raman data were collected in the epi-direction with an Olympus objective (50x magnification, 0.5 numerical aperture). The grating used had $2400 \mathrm{~cm}^{-1}$ grooves/millimeters (resolution $\pm 2 \mathrm{~cm}^{-1}$ ). A $100 \mu \mathrm{m}$ confocal pinhole and $300 \mu \mathrm{m}$ monochromator slit were used for data collection. The acquisition time for all materials was 3 and $10 \mathrm{~s}$ and were labelled accordingly throughout. Three areas across each sample were measured to obtain a representative signal for the given material and were averaged for all data shown. ImageJ analysis software was used to analyze optical images. The Raman spectra were processed with Igor Pro 6.36 (Wavemetrics, Inc., Lake Oswego, OR). Control measurements of $\mathrm{y}-\mathrm{Al}_{2} \mathrm{O}_{3}$, bulk $\mathrm{MoO}_{3}$, and a blank coverslip were also performed to confirm the Raman signal within the samples.

\subsection{Catalytic reactions}

To investigate product selectivity from model compound HDO and ex-situ HDO of lignin pyrolysis vapors, a single-shot tandem micropyrolyzer (Rx-3050tr, Frontier Labs, Japan) was employed. A full description and schematic representation of the tandem micropyrolyzer has been shown previously. ${ }^{1}$ This system 
consists of two reactors in series where pyrolysis or volatilization takes place in the first reactor, and HDO occurs in the second reactor. The temperature of these two reactors can be controlled independently between 313 and $1173 \mathrm{~K}$. The interfaces between the two reactors and between the second reactor and the GC were heated to $573 \mathrm{~K}$ to avoid vapor condensation.

For model compound experiments, $0.2 \mu \mathrm{L}$ of anisole, $0.2 \mu \mathrm{L}$ of 4-propylphenol, or $0.4 \mu \mathrm{L}$ of 2-butanone was injected into the top of the first reactor using a $0.5-\mu \mathrm{L}$ syringe (Hamilton) and a Chaney adaptor to ensure injection consistency. The temperature of the first reactor was set at $573 \mathrm{~K}$, well-above the boiling point of any of the three model compounds to ensure instant vaporization. For lignin experiments, $\sim 0.5 \mathrm{mg}$ of DPL was loaded into stainless steel cups. The cups were then placed above the pyrolyzer using a hook and remained for at least $2 \mathrm{~min}$ to sweep out residual air before dropping into the pyrolyzer at $773 \mathrm{~K}$. The pyrolysis vapors were swept using $120 \mathrm{ml} \mathrm{min}^{-1} \mathrm{H}_{2}$ into the HDO reactor (673 K) containing a catalyst bed composed of the desired amount of catalyst mixed with acid-washed glass beads fixed between two layers of quartz wool. Acid-washed glass beads (150-212 $\mu \mathrm{m}$, Sigma-Aldrich) were completely inactive under the reaction conditions and used as inert diluents to keep the catalyst bed length the same for all reactions.

\subsection{Product analysis}

The pyrolysis or HDO products were analyzed using a gas chromatograph (GC - Agilent 7890B) coupled with TCD, flame ionization detector (FID), and MS (Agilent 5977A). The GC was programmed to initiate at $303 \mathrm{~K}$, hold for $7 \mathrm{~min}$ and then ramp to $573 \mathrm{~K}$ at $10 \mathrm{~K} / \mathrm{min}$. Non-condensable species were separated using a GasPro column (Agilent GS-GasPro) and quantified by TCD. Condensable species were separated using two medium polarity columns (Agilent VF-1701 MS) and identified and quantified by MS and FID, respectively. TCD was calibrated for $\mathrm{CO}, \mathrm{CO}_{2}$, and $\mathrm{C}_{1}-\mathrm{C}_{5}$ alkanes and alkenes using a custom ordered gas mixture from Airgas containing $5 \% \mathrm{CO}, 5 \% \mathrm{CO}_{2}, 2 \%$ methane, $2 \%$ ethane, $2 \%$ ethylene, $2 \%$ propane, $2 \%$ propylene, $1 \% i$-butane, $2 \% n$-butane, $4 \% 1$-butene, $2 \%$ cis-2-butene, $1 \%$ trans-2-butene, $2 \% n$ pentane, and 1\% 1-pentene in balance He. The calibration was done using a 1-mL Hamilton syringe with a sample lock at volumes between 0.1 to $1 \mathrm{ml}$. The FID was calibrated using a 5-point standard calibration curve. A list of compounds used for the FID calibration is presented in Table S1.

The reactant conversion, and selectivity and yield of products are reported on a carbon basis as follows:

$$
\text { Conversion }(C \%)=\frac{\text { carbon mass of consumed reactant }}{\text { carbon mass in reactant feed }} \times 100 \%
$$




$$
\begin{gathered}
\text { Selectivity }(C \%)=\frac{\text { carbon mass of product }}{\text { carbon mass of all products }} \times 100 \% \\
\text { Yield }(C \%)=\frac{\text { carbon mass of product }}{\text { carbon mass in reactant feed }} \times 100 \%
\end{gathered}
$$

where the carbon mass of the product was measured by either TCD or FID, and carbon mass of reactant feed was calculated based on the amount of feed injected for liquid feeds and based on TGA and elemental analysis for the lignin feed. Char yields were measured by weighing the sample cups before and after pyrolysis using a micro-balance (Metler Toledo XP2U, $d=0.1 \mu \mathrm{g}$ ). Similar to our previous report, the pyrolytic char was assumed to be composed of $90 \%$ carbon for the purpose of reporting carbon yields. ${ }^{2}$

Coke measurements were done using a thermogravimetric analyzer (TGA, Netzsch STA449 F1) coupled with MS (QMS 403 Aëolos Quadro). $100 \mathrm{ml} \mathrm{min}^{-1}$ of a gas mixture containing 2\% $\mathrm{O}_{2}, 2 \% \mathrm{Ar}$ (internal standard), and the balance He was employed to burn off the coke. The furnace temperature was initially set to $313 \mathrm{~K}$ for $15 \mathrm{~min}$, ramped to $923 \mathrm{~K}$ at a rate of $10 \mathrm{~K} / \mathrm{min}$, and finally held at $923 \mathrm{~K}$ for $15 \mathrm{~min} . \mathrm{CO}_{2}$ (the only product) and Ar were monitored using the $\mathrm{MS}$ at $m / z=44$ and 40 , respectively. The amount of carbon was calculated based on the $\mathrm{CO}_{2}$ evolution. TG-MS calibration was done using a calcium oxalate standard (Sigma-Aldrich, $\geq 99.9 \%$ trace metals basis). ${ }^{3}$ 

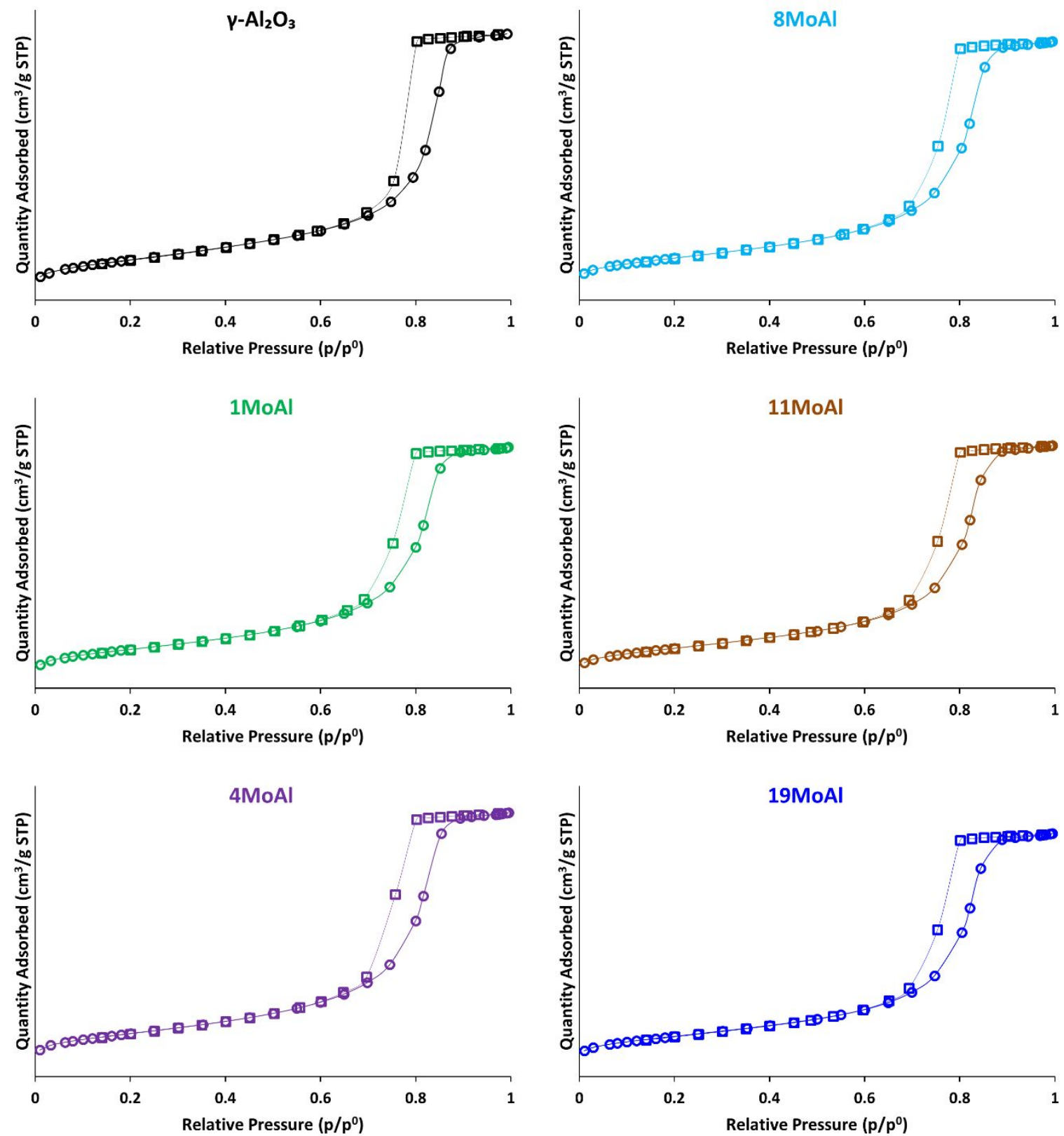

Figure S3. $\mathrm{N}_{2}$-adsorption/desorption isotherms of as-prepared catalyst samples (Circles and squares represent adsorption and desorption branches, respectively) 


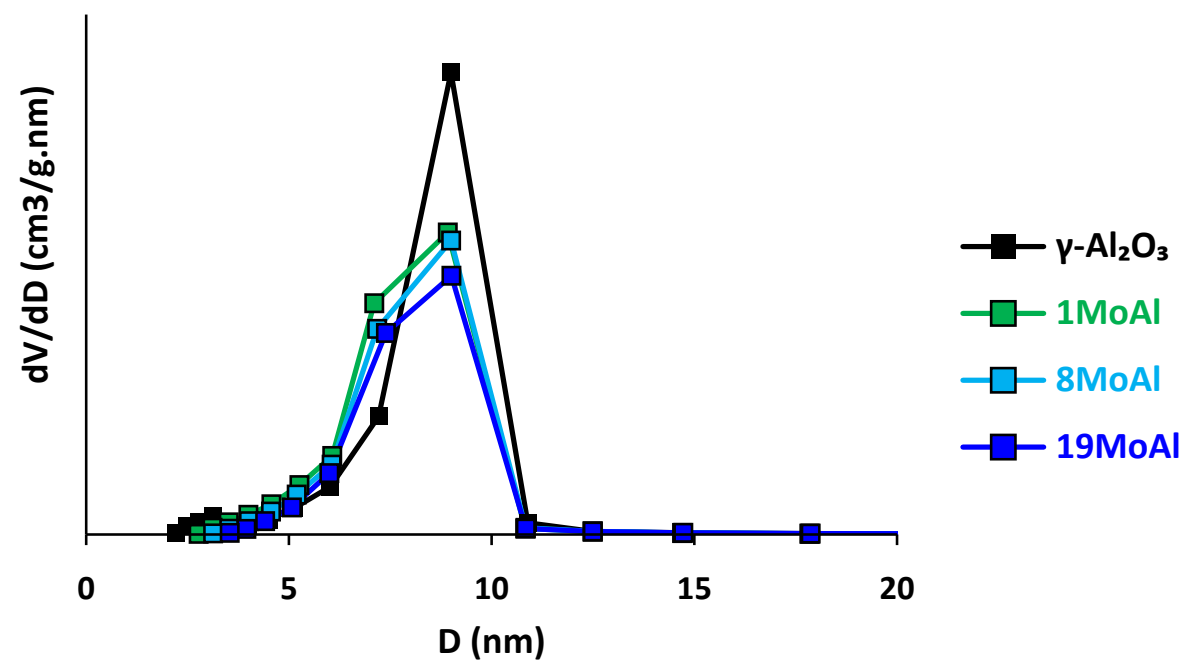

Figure S4. Pore size distribution of selected as-prepared catalyst samples calculated from the desorption branch of the BJH model (we excluded some samples to avoid overcrowding the graph)
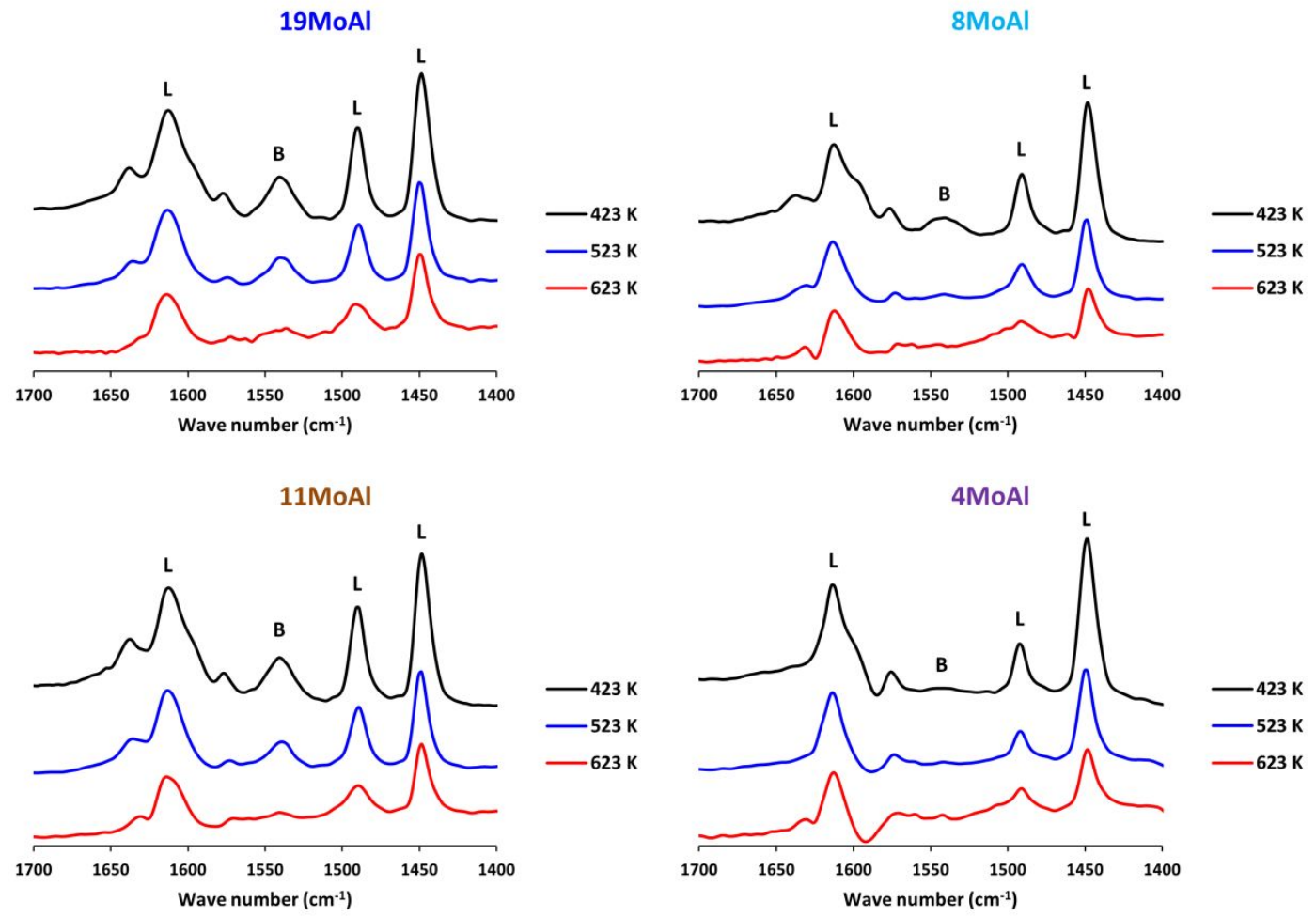

Figure S5. DRIFTS of 19MoAl-4MoAl samples (reduced in-situ at $673 \mathrm{~K}$ for $1 \mathrm{~h}$ and pyridinated at $423 \mathrm{~K}$ ) after evacuation at 423,523 , and $623 \mathrm{~K}$ ( $\mathrm{L}$ and B correspond to peaks related to Lewis and Brønsted acid sites, respectively) 


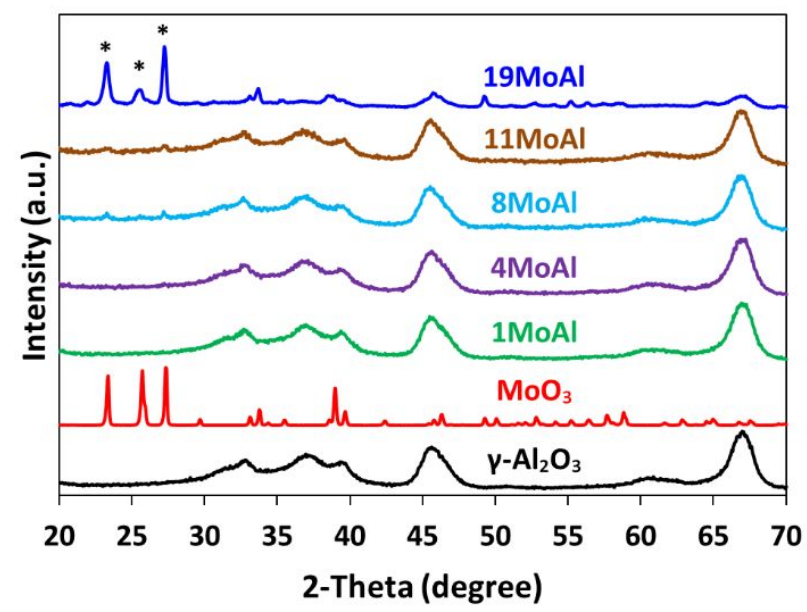

Figure S6. Powder XRD patterns of as-prepared catalyst samples normalized by maximum peak intensity for each spectrum (asterisks represent the peaks associated with orthorombic $\mathrm{MoO}_{3}$ phase) 

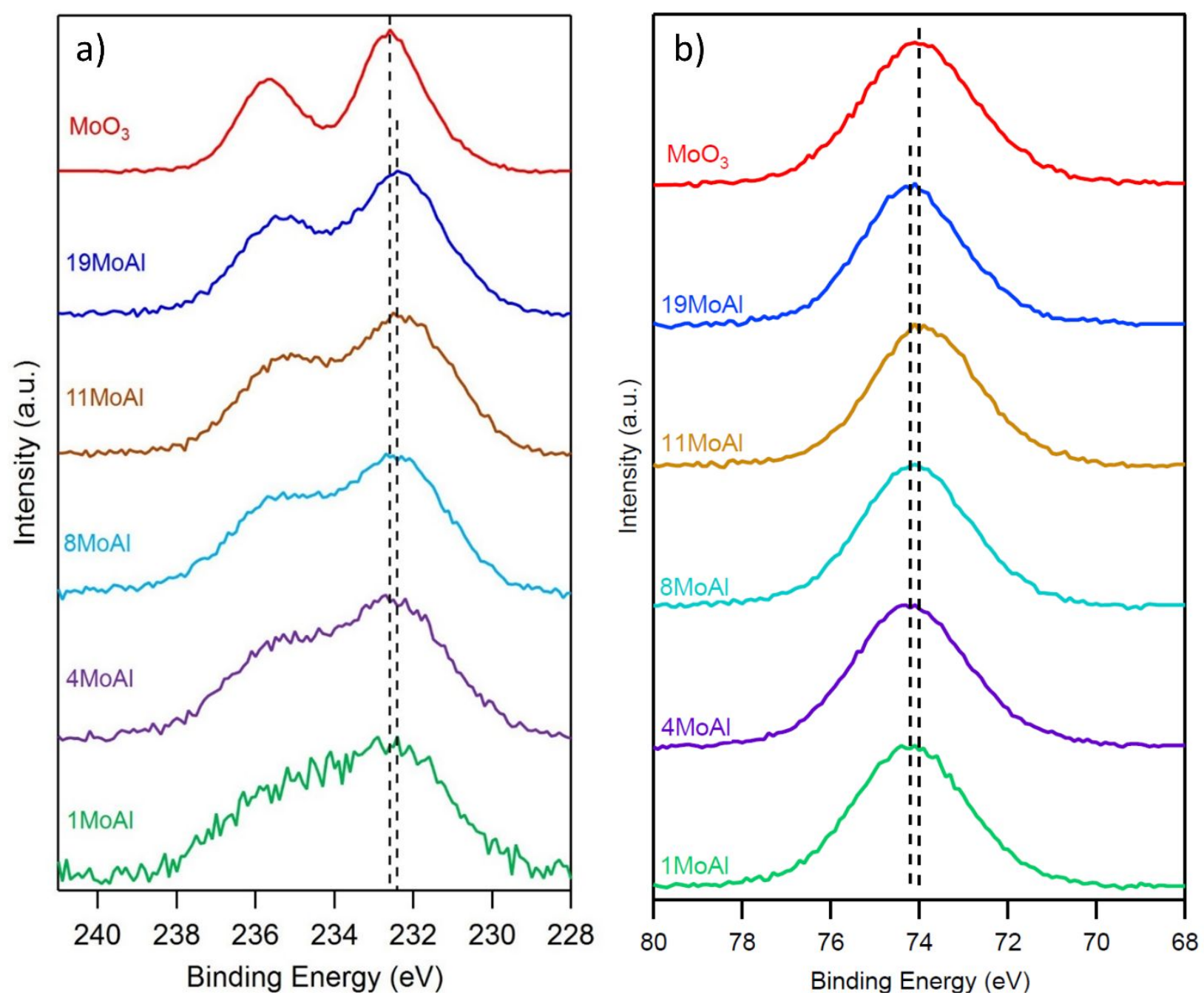

Figure S7. XPS spectra of the a) Mo $3 d$ and b) $A / 2 p$ binding energies of as-prepared catalyst samples normalized by maximum peak intensity for each spectrum (dashed lines are included to guide the reader's eyes) 

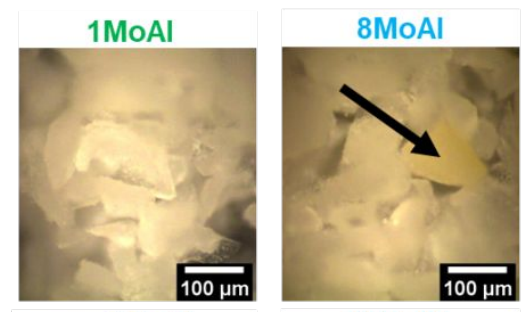

$4 \mathrm{MoAl}$

$11 \mathrm{MoAl}$
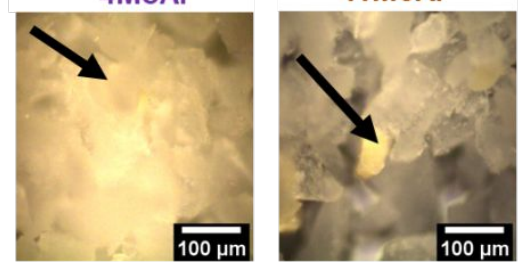

19MoAl

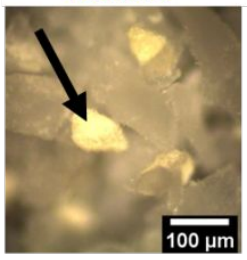

Optical Images

10x Magnification

Figure S8. Optical images of as-prepared catalyst samples (the arrows point to the $\mathrm{MoO}_{3}$-rich areas in each sample where Raman spectra were collected)

Table S2. Experimental Raman peaks and Raman peak assignments of molybdenum oxide catalysts

\begin{tabular}{|c|c|}
\hline $\begin{array}{c}\text { Raman peaks }\left(\mathrm{cm}^{-1}\right) \\
\text { as observed in Figure } 5 \mathrm{~A}\end{array}$ & Raman peak assignment ${ }^{4-6}$ \\
\hline 81 & $\mathrm{~A}_{\mathrm{g}}$, translational rigid $\mathrm{MoO}_{4}$ chain mode, $\mathrm{T}_{\mathrm{a}}$ \\
\hline 93 & $\mathrm{~B}_{2 \mathrm{~g}}$, translational rigid $\mathrm{MoO}_{4}$ chain mode, $\mathrm{T}_{\mathrm{a}}$ \\
\hline 113 & $\mathrm{~B}_{2 \mathrm{~g}}$, translational rigid $\mathrm{MoO}_{4}$ chain mode, $\mathrm{T}_{\mathrm{c}}$ \\
\hline 124 & $\mathrm{~B}_{3 \mathrm{~g}}$, translational rigid $\mathrm{MoO}_{4}$ chain mode, $\mathrm{T}_{\mathrm{c}}$ \\
\hline 152 & $\mathrm{~A}_{\mathrm{g}} / \mathrm{B}_{1 \mathrm{~g}}$, translational rigid $\mathrm{MoO}_{4}$ chain mode, $\mathrm{T}_{\mathrm{b}}$ \\
\hline 192 & $\mathrm{~B}_{2 \mathrm{~g},} \tau \mathrm{O}=\mathrm{M}=\mathrm{O}$ twist \\
\hline 213 & $A_{g}$, rotational rigid $\mathrm{MoO}_{4}$ chain mode, $R_{c}$ \\
\hline 238 & $\mathrm{~B}_{3 g}, \tau \mathrm{O}=\mathrm{M}=0$ twist \\
\hline 286 & $\mathrm{~B}_{2 \mathrm{~g}}, \delta \mathrm{O}=\mathrm{M}=\mathrm{O}$ wagging \\
\hline 332 & $A_{g}, B_{1 g}, \delta$ O-M-O bend \\
\hline 374 & $\mathrm{~B}_{1 \mathrm{~g}}$ \\
\hline 467 & $\mathrm{~A}_{\mathrm{g}}, \mathrm{V}_{\mathrm{as}} \mathrm{O}-\mathrm{M}-\mathrm{O}$ stretch \\
\hline 662 & $\mathrm{~B}_{2 \mathrm{~g}}, \mathrm{~B}_{3 \mathrm{~g}}, \mathrm{v}_{\mathrm{as}} \mathrm{O}-\mathrm{M}-\mathrm{O}$ stretch \\
\hline 814 & $A_{g}, v_{a s} M=O$ stretch \\
\hline 927 & $\mathrm{M}=\mathrm{O}$ stretching \\
\hline 993 & $A_{g}, v_{a s} M=0$ stretch \\
\hline
\end{tabular}


Table S3. Carbon yield of products from the HDO of anisole. Reaction conditions: $120 \mathrm{~mL} \mathrm{~min}^{-1} \mathrm{H}_{2}(\sim 1.7 \mathrm{bar}) ; 0.2 \mu \mathrm{L}$ feed injection at $573 \mathrm{~K}$; catalyst bed at $673 \mathrm{~K}$, catalyst pre-reduced $1 \mathrm{~h}$.

\begin{tabular}{|c|c|c|c|c|c|c|c|}
\hline Catalyst & $\begin{array}{c}\mathrm{MoO}_{3} \\
(3 \mathrm{mg})\end{array}$ & $\begin{array}{r}\text { 19MoAl } \\
\text { (6 mg) }\end{array}$ & $\begin{array}{r}\text { 11MoAl } \\
\text { (6 mg) }\end{array}$ & $\begin{array}{l}\text { 8MoAl } \\
(6 \mathrm{mg})\end{array}$ & $\begin{array}{l}\text { 4MoAl } \\
\text { (6 mg) }\end{array}$ & $\begin{array}{l}\text { 1MoAl } \\
\text { (6 mg) }\end{array}$ & $\begin{array}{r}\mathbf{p}-\mathrm{Al}_{\mathbf{2}} \mathbf{O}_{\mathbf{3}} \\
(6 \mathrm{mg})\end{array}$ \\
\hline Conversion (C\%) & 63.8 & 94.9 & 89.9 & 95.4 & 92.9 & 76.6 & 75.7 \\
\hline \multicolumn{8}{|l|}{ Yield (C\%) } \\
\hline $\mathrm{C}_{6}-\mathrm{C}_{8}$ aromatics & 46.1 & 65.2 & 60.0 & 66.2 & 44.0 & 6.1 & 0.3 \\
\hline Benzene & 38.2 & 37.8 & 32.5 & 31.8 & 15.9 & 1.4 & 0.1 \\
\hline Toluene & 6.9 & 20.3 & 19.7 & 24.4 & 19.3 & 3.0 & 0.1 \\
\hline Xylenes & 1.0 & 7.2 & 7.8 & 10.0 & 8.8 & 1.7 & 0.1 \\
\hline $\mathrm{C}_{9}+$ aromatics & 0.1 & 9.2 & 10.6 & 9.5 & 4.7 & 1.9 & 1.4 \\
\hline Trimethylbenzenes & 0.1 & 2.8 & 3.2 & 3.3 & 1.6 & 0.5 & 0.4 \\
\hline Tetramethylbenzenes & 0.0 & 1.6 & 1.5 & 1.0 & 0.3 & 0.1 & 0.0 \\
\hline Pentamethylbenzene & 0.0 & 1.6 & 1.7 & 1.8 & 1.9 & 1.1 & 0.8 \\
\hline Hexamethylbenzene & 0.0 & 3.2 & 4.2 & 3.4 & 1.0 & 0.3 & 0.2 \\
\hline Phenolics & 1.6 & 9.3 & 10.6 & 12.8 & 14.1 & 16.5 & 10.5 \\
\hline Phenol & 1.3 & 4.0 & 4.8 & 5.3 & 5.8 & 6.7 & 4.9 \\
\hline Cresols & 0.2 & 2.4 & 2.6 & 3.4 & 4.1 & 5.8 & 3.1 \\
\hline Dimethylphenols & 0.1 & 1.9 & 1.8 & 2.5 & 2.0 & 1.7 & 1.3 \\
\hline Trimethylphenols & 0.0 & 0.8 & 0.9 & 1.1 & 1.2 & 1.5 & 0.9 \\
\hline Tetramethylphenols & 0.0 & 0.2 & 0.4 & 0.5 & 1.0 & 0.9 & 0.4 \\
\hline Methylanisoles & 1.6 & 0.0 & 0.0 & 0.0 & 0.0 & 0.0 & 0.0 \\
\hline Diaromatics & 0.0 & 0.0 & 0.0 & 0.0 & 1.6 & 1.7 & 0.6 \\
\hline Others $^{a}$ & 0.4 & 0.6 & 0.4 & 0.5 & 0.3 & 0.8 & 0.4 \\
\hline Methane & 7.4 & 1.8 & 1.0 & 0.6 & 0.2 & 0.1 & 0.0 \\
\hline Coke & 0.3 & 0.4 & 0.5 & 1.2 & 3.8 & 18.7 & 26.8 \\
\hline Total C balance & 93.7 & 91.7 & 93.2 & 95.5 & 75.8 & 69.1 & 64.2 \\
\hline
\end{tabular}

a: $\mathrm{CO}_{2}$, dimethylehter, methanol, methylcyclopentane, 3-methylcyclopentene, 2-methyl-1-pentene, and cyclohexene 
Table S4. Carbon yield of products from the HDO of 4-propylphenol. Reaction conditions: $120 \mathrm{~mL} \mathrm{~min}^{-1} \mathrm{H}_{2}(\sim 1.7$ bar); $0.2 \mu \mathrm{L}$ feed injection at $573 \mathrm{~K}$; catalyst bed at $673 \mathrm{~K}$, catalyst pre-reduced $1 \mathrm{~h}$.

\begin{tabular}{|c|c|c|c|c|c|c|c|}
\hline Catalyst & $\begin{array}{l}\mathbf{M o O}_{3} \\
(3 \mathrm{mg})\end{array}$ & $\begin{array}{c}\text { 19MoAl } \\
\text { (6 mg) }\end{array}$ & $\begin{array}{c}\text { 11MoAl } \\
\text { (6 mg) }\end{array}$ & $\begin{array}{l}\text { 8MoAl } \\
(6 \mathrm{mg})\end{array}$ & $\begin{array}{l}\text { 4MoAl } \\
(6 \mathrm{mg})\end{array}$ & $\begin{array}{l}\text { 1MoAl } \\
(6 \mathrm{mg})\end{array}$ & $\begin{array}{c}\mathrm{V}-\mathrm{Al}_{\mathbf{2}} \mathrm{O}_{3} \\
(6 \mathrm{mg})\end{array}$ \\
\hline Conversion (C\%) & 75.9 & 92.8 & 80.9 & 83.6 & 88.1 & 73.2 & 79.3 \\
\hline \multicolumn{8}{|l|}{ Yield (C\%) } \\
\hline Benzene & 3.1 & 16.6 & 10.7 & 14.0 & 20.3 & 2.8 & 0.0 \\
\hline Toluene & 2.1 & 5.1 & 2.2 & 3.3 & 4.7 & 0.9 & 0.0 \\
\hline Ethylbenzene & 1.2 & 3.2 & 2.1 & 2.3 & 2.5 & 0.6 & 0.0 \\
\hline Propylbenzene & 71.0 & 58.2 & 55.0 & 49.3 & 28.9 & 4.2 & 0.1 \\
\hline $\mathrm{C}_{10}+$ aromatics & 0.9 & 5.5 & 9.9 & 11.7 & 11.2 & 9.9 & 2.2 \\
\hline Phenol & 0.0 & 0.5 & 0.7 & 1.3 & 2.3 & 6.1 & 7.3 \\
\hline Methyl/ethylphenols & 0.0 & 0.0 & 0.0 & 0.0 & 0.6 & 1.8 & 2.3 \\
\hline Propane & 1.2 & 1.1 & 0.0 & 0.0 & 0.0 & 0.0 & 0.0 \\
\hline Propylene & 0.1 & 1.0 & 1.4 & 2.4 & 6.0 & 3.1 & 3.9 \\
\hline Others $^{a}$ & 0.0 & 0.0 & 0.0 & 0.0 & 0.3 & 0.6 & 0.6 \\
\hline Coke & 0.2 & 1.1 & 1.9 & 2.3 & 5.3 & 30.9 & 50.1 \\
\hline Total C balance & 103.9 & 99.5 & 102.8 & 103.0 & 94.1 & 87.9 & 87.4 \\
\hline
\end{tabular}

a: 4-Propylcyclohexene and 2-Methyl-6-propylphenol 
Table S5. Carbon yield of products from the HDO of 2-butanone. Reaction conditions: $120 \mathrm{~mL} \mathrm{~min}^{-1} \mathrm{H}_{2}$ ( 1.7 bar); $0.4 \mu \mathrm{L}$ feed injection at $573 \mathrm{~K}$; catalyst bed at $673 \mathrm{~K}$, catalyst pre-reduced $1 \mathrm{~h}$.

\begin{tabular}{|c|c|c|c|c|c|c|c|}
\hline Catalyst & $\begin{array}{c}\mathbf{M o O}_{3} \\
(1 \mathrm{mg})\end{array}$ & $\begin{array}{r}\text { 19MoAl } \\
\text { (3 mg) }\end{array}$ & $\begin{array}{r}\text { 11MoAl } \\
\text { (3 mg) }\end{array}$ & $\begin{array}{l}\text { 8MoAl } \\
\text { (3 mg) }\end{array}$ & $\begin{array}{l}\text { 4MoAl } \\
\text { (3 mg) }\end{array}$ & $\begin{array}{l}\text { 1MoAl } \\
\text { (3 mg) }\end{array}$ & $\begin{array}{r}\mathbf{v}-\mathrm{Al}_{\mathbf{2}} \mathbf{O}_{\mathbf{3}} \\
(3 \mathrm{mg})\end{array}$ \\
\hline Conversion (C\%) & 61.2 & 59.0 & 48.9 & 44.4 & 41.9 & 48.9 & 56.5 \\
\hline \multicolumn{8}{|l|}{ Yield (C\%) } \\
\hline Hydrocarbons & 56.0 & 47.6 & 28.8 & 23.0 & 14.1 & 11.5 & 14.1 \\
\hline$C_{1}-C_{3}{ }^{a}$ & 1.2 & 0.6 & 0.3 & 0.3 & 0.2 & 0.1 & 0.1 \\
\hline i-Butane & 0.4 & 0.1 & 0.0 & 0.0 & 0.0 & 0.0 & 0.0 \\
\hline n-Butane & 7.8 & 3.4 & 0.5 & 0.2 & 0.1 & 0.0 & 0.0 \\
\hline 1-Butene & 9.2 & 7.8 & 4.4 & 3.3 & 1.7 & 1.1 & 1.6 \\
\hline trans-2-Butene & 17.5 & 9.8 & 4.1 & 2.7 & 1.3 & 0.8 & 1.1 \\
\hline cis-2-Butene & 13.8 & 11.9 & 7.1 & 5.1 & 2.7 & 1.9 & 2.7 \\
\hline$C_{5}-C_{7}{ }^{b}$ & 2.0 & 2.6 & 2.3 & 2.1 & 1.6 & 1.3 & 1.4 \\
\hline$C_{8}$ Alkenes & 2.8 & 5.2 & 3.0 & 1.9 & 0.5 & 0.3 & 0.4 \\
\hline$C_{8}$ Alkadiene & 0.4 & 3.1 & 3.2 & 2.9 & 1.8 & 1.5 & 1.6 \\
\hline$C_{8}$ aromatics & 0.7 & 0.9 & 0.8 & 0.7 & 0.3 & 0.3 & 0.0 \\
\hline$C_{12}$ aromatics & 0.2 & 2.1 & 3.1 & 3.7 & 4.0 & 4.2 & 5.2 \\
\hline Oxygenates & 0.9 & 6.4 & 9.7 & 11.5 & 11.7 & 10.9 & 11.1 \\
\hline 2-Butanol & 0.3 & 0.2 & 0.1 & 0.1 & 0.0 & 0.0 & 0.0 \\
\hline$C_{3}-C_{7}$ Ketones $^{c}$ & 0.0 & 0.7 & 0.8 & 1.0 & 1.5 & 1.4 & 1.6 \\
\hline$C_{8}$ Ketones & 0.6 & 5.4 & 8.7 & 10.4 & 10.2 & 9.5 & 9.5 \\
\hline Coke & 0.0 & 0.1 & 0.1 & 0.2 & 0.9 & 1.6 & 3.3 \\
\hline Total C balance & 95.7 & 95.1 & 89.8 & 90.3 & 84.8 & 75.2 & 72.1 \\
\hline \multicolumn{8}{|l|}{ Ratios } \\
\hline butanes/enes & 0.20 & 0.12 & 0.03 & 0.02 & 0.01 & 0.00 & 0.00 \\
\hline 1-ene/2-enes & 0.29 & 0.36 & 0.40 & 0.43 & 0.43 & 0.42 & 0.41 \\
\hline cis/trans & 0.79 & 1.22 & 1.75 & 1.87 & 2.14 & 2.32 & 2.50 \\
\hline
\end{tabular}

a: Methane, ethane, ethylene, propane, and propylene; ${ }^{b}$ : $C_{5}$ alkanes and $C_{5}-C_{7}$ alkenes; ${ }^{c}$ : acetone, $C_{5}$ ketones, and $C_{7}$ ketones. 
Table S6. Carbon yield of products from the HDO of DPL pyrolysis vapors. Reaction conditions: $120 \mathrm{~mL} \mathrm{~min}^{-1} \mathrm{H}_{2}$ ( 1.7 bar); $0.5 \mathrm{mg}$ DPL pyrolyzed at $773 \mathrm{~K} ; 10 \mathrm{mg}$ supported catalyst or $5 \mathrm{mg} \mathrm{MoO}$ at $673 \mathrm{~K}$, catalyst pre-reduced 1 h.

\begin{tabular}{|c|c|c|c|c|c|c|c|c|}
\hline \multirow[b]{2}{*}{ Compounds } & \multirow[b]{2}{*}{ Pyrolysis } & \multicolumn{7}{|c|}{ Catalysts } \\
\hline & & $\mathrm{V}-\mathrm{Al}_{2} \mathrm{O}_{3}$ & 1MoAl & 4MoAl & 8MoAl & 11MoAl & 19MoAl & $\mathrm{MoO}_{3}$ \\
\hline \multicolumn{9}{|l|}{ Yield (C\%) } \\
\hline CO & 1.2 & 3.7 & 4.0 & 4.2 & 4.5 & 4.6 & 5.3 & 4.3 \\
\hline $\mathrm{CO}_{2}$ & 2.0 & 2.6 & 2.9 & 2.9 & 2.9 & 2.9 & 2.5 & 2.4 \\
\hline $\mathrm{CH}_{4}$ & 0.0 & 0.4 & 0.6 & 0.9 & 1.6 & 2.0 & 2.0 & 3.2 \\
\hline Alkanes & 0.1 & 0.4 & 0.5 & 0.9 & 2.0 & 2.5 & 6.4 & 9.0 \\
\hline \multicolumn{9}{|l|}{ Alkane selectivity } \\
\hline Ethane & 0.0 & 0.0 & 0.0 & 3.5 & 5.1 & 10.4 & 4.5 & 8.9 \\
\hline Propane & 77.5 & 27.4 & 20.1 & 14.7 & 10.9 & 8.1 & 17.5 & 27.5 \\
\hline Butane & 22.5 & 15.1 & 21.4 & 14.7 & 10.4 & 10.4 & 27.0 & 28.8 \\
\hline Pentane & 0.0 & 22.7 & 25.0 & 21.9 & 33.7 & 29.5 & 33.4 & 22.7 \\
\hline Hexane & 0.0 & 0.0 & 0.0 & 0.0 & 15.0 & 19.7 & 17.7 & 12.1 \\
\hline$C_{7}+$ & 0.0 & 34.8 & 33.5 & 45.2 & 24.9 & 22.0 & 0.0 & 0.0 \\
\hline Alkenes & 0.2 & 2.6 & 3.3 & 4.6 & 5.6 & 5.9 & 3.7 & 4.3 \\
\hline \multicolumn{9}{|l|}{ Alkene selectivity } \\
\hline Ethylene & 11.5 & 5.1 & 7.6 & 8.4 & 6.3 & 9.2 & 7.3 & 12.6 \\
\hline Propylene & 0.0 & 13.4 & 14.7 & 18.8 & 23.0 & 27.5 & 36.8 & 40.9 \\
\hline Butene & 88.5 & 21.5 & 24.2 & 27.2 & 27.1 & 29.3 & 34.6 & 27.8 \\
\hline Pentene & 0.0 & 3.2 & 2.8 & 8.7 & 12.8 & 18.9 & 10.5 & 7.1 \\
\hline Hexene & 0.0 & 21.7 & 14.4 & 13.4 & 13.8 & 15.1 & 10.9 & 11.5 \\
\hline$C_{7}+$ & 0.0 & 17.2 & 13.8 & 5.6 & 4.0 & 0.0 & 0.0 & 0.0 \\
\hline alkadi(tri)ene & 0.0 & 17.9 & 22.5 & 17.9 & 13.0 & 0.0 & 0.0 & 0.0 \\
\hline $\begin{array}{l}\text { Monoaromatics } \\
\text { (saturated) }{ }^{a}\end{array}$ & 0.5 & 1.5 & 2.2 & 6.0 & 10.9 & 13.4 & 14.7 & 16.4 \\
\hline \multicolumn{9}{|l|}{ MAR selectivity } \\
\hline Benzene & 22.2 & 22.5 & 18.8 & 18.3 & 20.8 & 22.5 & 25.1 & 24.0 \\
\hline Toluene & 39.6 & 29.7 & 33.8 & 32.2 & 25.7 & 24.7 & 28.2 & 27.8 \\
\hline$C_{8}$ aromatics & 38.2 & 23.6 & 26.9 & 33.1 & 37.5 & 30.9 & 30.0 & 33.7 \\
\hline$C_{9}+$ aromatics & 0.0 & 24.2 & 20.5 & 16.4 & 15.9 & 21.9 & 16.7 & 14.5 \\
\hline $\begin{array}{l}\text { Monoaromatics } \\
\text { (unsaturated) }{ }^{a}\end{array}$ & 0.0 & 0.3 & 0.4 & 0.6 & 0.9 & 1.7 & 0.7 & 0.3 \\
\hline Diaromatics & 0.2 & 0.5 & 0.6 & 0.7 & 1.0 & 1.5 & 1.0 & 0.2 \\
\hline $\begin{array}{l}\text { Polyaromatic } \\
\text { hydrocarbons }\end{array}$ & 0.1 & 0.5 & 0.6 & 0.8 & 0.9 & 1.0 & 0.0 & 0.0 \\
\hline $\begin{array}{l}\mathrm{N} \text {-containing } \\
\text { compounds }\end{array}$ & 1.1 & 0.2 & 0.5 & 0.4 & 0.3 & 0.0 & 0.0 & 0.0 \\
\hline $\begin{array}{l}\text { Non-phenolic } \\
\text { oxygenates }\end{array}$ & 4.6 & 0.5 & 0.6 & 0.4 & 0.5 & 0.2 & 0.0 & 0.0 \\
\hline $\begin{array}{l}\text { Phenolic } \\
\text { oxygenates }\end{array}$ & 9.8 & 0.0 & 0.0 & 0.0 & 0.0 & 0.0 & 0.0 & 0.0 \\
\hline Coke & - & 20.3 & 14.7 & 8.9 & 4.6 & 4.2 & 3.5 & 2.4 \\
\hline
\end{tabular}




\begin{tabular}{llllllllc|} 
Char & 58.3 & 58.3 & 58.3 & 58.3 & 58.3 & 58.3 & 58.3 & 58.3 \\
\hline Total Carbon & $\mathbf{7 7 . 9}$ & $\mathbf{9 1 . 9}$ & $\mathbf{8 9 . 1}$ & $\mathbf{8 9 . 7}$ & $\mathbf{9 4 . 0}$ & $\mathbf{9 8 . 1}$ & $\mathbf{9 8 . 1}$ & $\mathbf{1 0 0 . 8}$ \\
\hline
\end{tabular}

a: MAR (sat.): Monoaromatics with saturated side chains, MAR (unsat.): Monoaromatics with unsaturated side chains. 

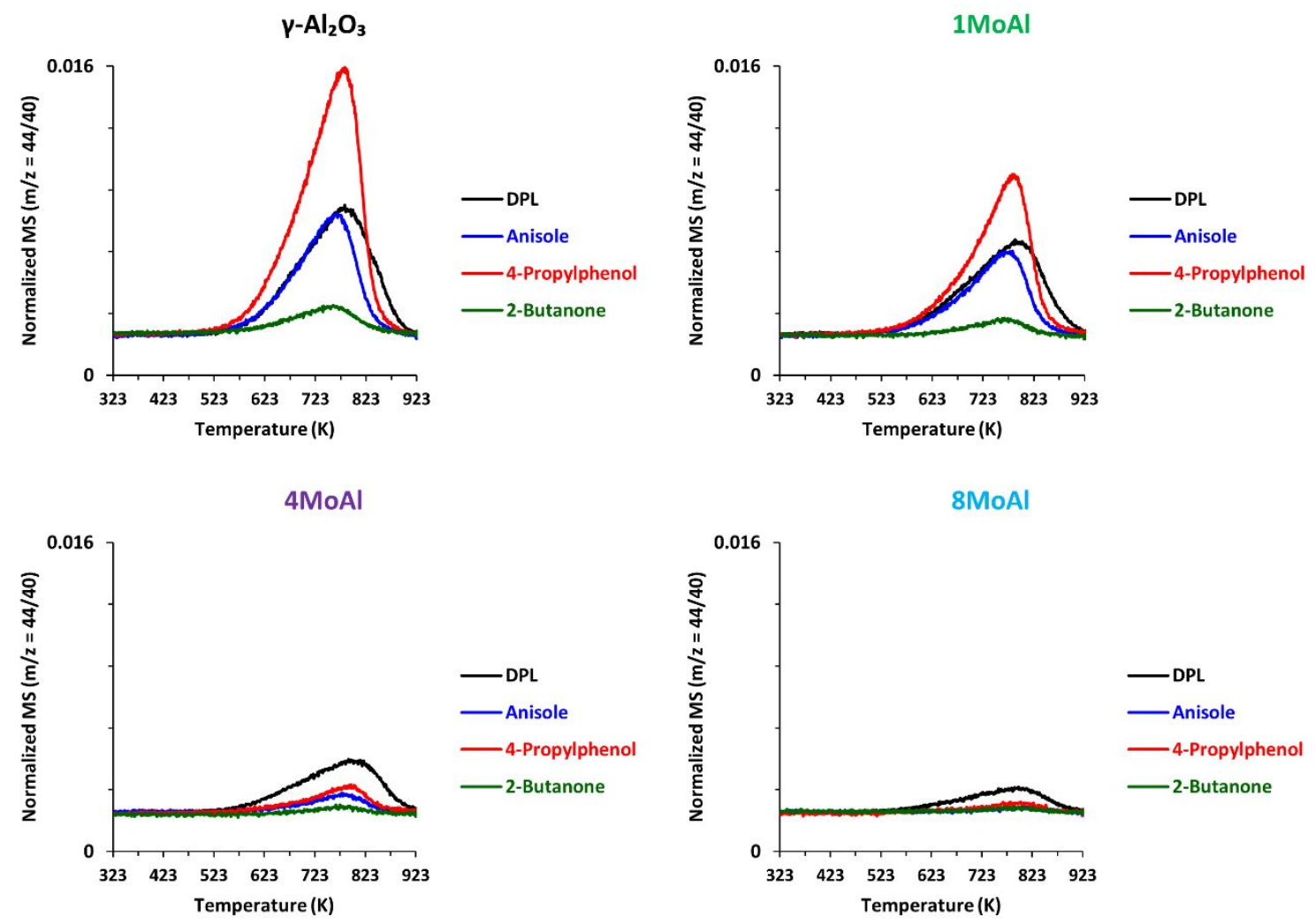

Figure S9. $\mathrm{CO}_{2}$ evolution during coke combustion of used catalysts after HDO of different feedstocks

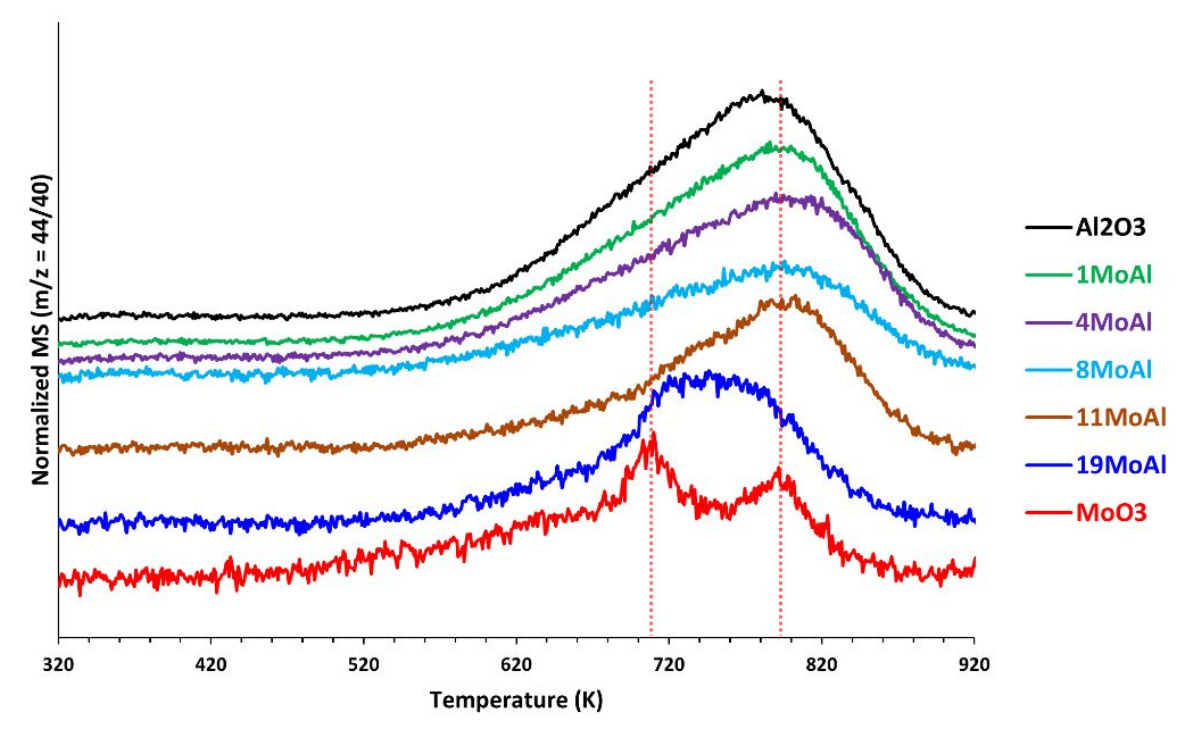

Figure S10. $\mathrm{CO}_{2}$ evolution during coke combustion of used catalysts after HDO of DPL (normalized by maximum peak intensity for each spectrum) 


\section{References}

1. Wang, K.; Zhang, J.; Shanks, B. H.; Brown, R. C., Catalytic Conversion of Carbohydrate-Derived Oxygenates over Hzsm5 in a Tandem Micro-Reactor System. Green Chemistry 2015, 17, 557-564.

2. Saraeian, A.; Aui, A.; Gao, Y.; Wright, M. M.; Foston, M.; Shanks, B. H., Evaluating Lignin Valorization Via Pyrolysis and Vapor-Phase Hydrodeoxygenation for Production of Aromatics and Alkenes. Green Chemistry 2020, 22, 2513-2525..

3. Hotová, G.; Slovák, V., Quantitative Tg-Ms Analysis of Evolved Gases During the Thermal Decomposition of Carbon Containing Solids. Thermochimica Acta 2016, 632, 23-28.

4. $\quad$ Dieterle, M.; Weinberg, G.; Mestl, G., Raman Spectroscopy of Molybdenum Oxides Part I. Structural Characterization of Oxygen Defects in Moo 3-X by Dr Uv/Vis, Raman Spectroscopy and X-Ray Diffraction. Physical Chemistry Chemical Physics 2002, 4, 812-821.

5. $\quad$ Weckhuysen, B. M.; Jehng, J.-M.; Wachs, I. E., In Situ Raman Spectroscopy of Supported Transition Metal Oxide Catalysts: 1802- 1602 Isotopic Labeling Studies. The Journal of Physical Chemistry B 2000, 104, 7382-7387.

6. $\quad$ Py, M. A.; Schmid, P. E.; Vallin, J. T., Raman Scattering and Structural Properties of Moo 3. II Nuovo Cimento B (19711996) $1977,38,271-279$. 